\title{
Engaging With the STFM Conference on Medical Student Education: Proceedings and PRiMER
}

\author{
Christopher P. Morley, PhD | Jacob Prunuske, MD, MSPH
}

PRiMER. 2019;3:6.

Published: 2/5/2019 | DOI: 10.22454/PRiMER.2019.472580

The Society of Teachers of Family Medicine (STFM) Conference on Medical Student Education (MSE) is an annual event that brings together a dedicated set of attendees to improve the teaching and mentoring skills and strengthen the professional networks of family medicine educators. Presentations at MSE are diverse in style, and include symposia and workshops on skill building, the sharing of curricular innovations, and research on medical education. For a number of years, the journal Teaching and Learning in Medicine (TLM) sporadically published a selection of the best research abstracts from MSE and its precursor, the Predoctoral Education Conference. ${ }^{1-7}$

Given the core mission of PRiMER to advance the scholarship of family medicine educational research, ${ }^{8}$ and the need more generally to advance and encourage the movement of abstracts to publication, ${ }^{9,10}$ we have arranged to pick up where TLM has left off. The best educational research abstracts had been selected for the 2015 and 2017 MSE conferences, and we are thrilled to present those alongside this editorial. These papers should be cited as shown in the reference list below. ${ }^{11,12}$ PRiMER is working with the MSE Committee to develop a new set of guidelines and a new process for abstract selection and the publication of these selected abstracts.

\section{Corresponding Author}

Christopher P. Morley, PhD

Chair, Department of Public Health \& Preventive Medicine, Vice Chair for Research, Department of Family Medicine Associate Professor of Family Medicine, Public Health \& Psychiatry S.U.N.Y. Upstate Medical University morleycp@upstate.edu

\section{Author Affiliations}

Christopher P. Morley, PhD - S.U.N.Y. Upstate Medical University

Jacob Prunuske, MD, MSPH - Medical College of Wisconsin-Central Wisconsin, Wausau, WI

\section{References}

1. Chumley H. Abstracts from the Proceedings of the 2005 Annual Predoctoral Meeting of the Society for Teachers of Family Medicine (STFM). Teach Learn Med. 2005;17(4):391-395. https://doi.org/10.1207 /s15328015tlm1704_14

2. Chumley H, Steele DJ. ACE (Alliance for Clinical Education) abstracts: proceedings of the 2006 Annual Predoctoral Meeting of the Society for Teachers of Family Medicine (STFM). Teach Learn Med. 2006;18(4):356-361. https://doi.org/10.1207/s15328015tIm1804_14

3. Chumley H, Kim S. Abstracts from the Proceedings of the 2007 Annual Predoctoral Meeting of the Society for Teachers of Family Medicine (STFM). Teach Learn Med. 2008;20(1):84-91. https://doi.org/10.1080 /10401330701542826

4. Little DN, Hatch RL. Abstracts From the Proceedings of the 2010 Annual Predoctoral Education Conference of the Society of Teachers of Family Medicine (STFM). Teach Learn Med. 2011;23(1):90-95. https://doi.org 
$/ 10.1080 / 10401334.2011 .536899$

5. Mendoza MD, Little DN. Abstracts from the Proceedings of the 2011 Society of Teachers of Family Medicine (STFM) Conference on Medical Student Education. Teach Learn Med. 2012;24(1):90-96. https://doi.org /10.1080/10401334.2012.641493

6. Mendoza MD. Abstracts from the Proceedings of the 2012 Society of Teachers of Family Medicine (STFM) Conference on Medical Student Education. Teach Learn Med. 2013;25(1):109-14.

7. Robinson M, Mendoza MD. Abstracts From the Proceedings of the 2014 Society of Teachers of Family Medicine (STFM) Conference on Medical Student Education. Teach Learn Med. 2015;27(2):226-232. https://doi.org/10.1080/10401334.2015.1011739

8. Morley CP. Birthing a new journal: why bother? PRiMER. 2017;1:4. https://doi.org/10.22454/PRiMER.2017

9. Post RE, Mainous AG III, O'Hare KE, King DE, Maffei MS. Publication of research presented at STFM and NAPCRG conferences. Ann Fam Med. 2013;11(3):258-261. https://doi.org/10.1370/afm.1503

10. Weaver SP, Lastrapes E. Increasing family medicine scholarly presentations and the incidence of duplicate research abstracts. Fam Med. 2014;46(6):467-469.

11. Alavi M, Margo K. Selected Abstracts From the Proceedings of the 2015 Society of Teachers of Family Medicine (STFM) Conference on Medical Student Education. PRiMER. 1;3:4. https://doi.org/10.22454 /PRiMER.2019.564543

12. Liu L, Margo K. Selected Abstracts From the Proceedings of the 2017 Society of Teachers of Family Medicine Conference on Medical Student Education. PRiMER. 1;3:5. https://doi.org/10.22454/PRiMER.2019.299161

Copyright $(2019$ by the Society of Teachers of Family Medicine 